\title{
Houses, tranquility and progress in an área de milícia
}

\section{Marcella de Araujo Silva}

Departamento de Sociologia, Universidade Federal do Rio de Janeiro, Rio de Janeiro/RJ, Brasil

\begin{abstract}
This paper examines how power relations are organized and institutionalized in áreas de milícia (militiacontrolled areas) in the city of Rio de Janeiro. Drawing on my experience in public policies and research conducted in such areas, I look to understand the interweaving of politics and the security market in the vast but little known West Zone of the city. Reconstructing the story of one particular house in an área de milicia and tracing its connections back to the political genesis of the area's top leader - who figures in the now famous CPI das Milícias report - the paper reveals unforeseen interconnections between urban policies and the expanding illegal security market.
\end{abstract}

Keywords: houses, áreas de milícia, West Zone, security market, residents' associations. 


\section{Casas, tranquilidade e progresso em uma área de milícia}

\section{Resumo}

Este artigo analisa a forma de organização e institucionalização de relações de poder em uma área de milícia, na cidade do Rio de Janeiro. A partir de experiências minhas em políticas públicas e pesquisas em uma área de milícia, o artigo pretende compreender a relação imbricada entre a política e o mercado de segurança, na vasta, porém pouco conhecida, zona oeste da cidade. Reconstruindo a história de uma casa específica em uma comunidade em área de milícia e retraçando suas conexões com a gênese política da maior liderança da região, que figura no relatório da CPI das milícias, o artigo investiga as articulações não previstas entre políticas urbanas e o mercado ilegal de segurança.

Palavras-chave: casas, área de milícia, zona oeste, mercado de segurança, associações de moradores. 


\title{
Houses, tranquility and progress in an área de milícia
}

\author{
Marcella de Araujo Silva
}

\section{Introduction'}

On a late Monday afternoon, traveling on a Rio de Janeiro Line 1 metro train, two women chat about the places where they live. After one of them steps off the train at Glória station, the remaining woman turns to another passenger and continues to talk about her preference for Campo Grande ${ }^{2}$ over Copacabana. "It's far but an easy (tranquilo) 3 place to live. ${ }^{4}$ Just imagine having to deal with all those shootings..!" She speaks from first-hand experience, since she often visits friends living in the favelas of Rocinha and Salgueiro. "The houses are this small," she says, making a diminutive gesture with her hands. "And it's too steep," she adds. One of these friends had recently told her about a real estate bargain: $\mathrm{R} \$ 40,000$ for a kitchenette. "I would never trade my large house for a kitchenette just to live in Copacabana. I've spent 30 years improving my house. Today I have a backyard and a dog."

Seemingly quite banal, the talk hovers around a controversy: "Those who live around here think that it's violent over there, and those living over there think that it's violent here," as the woman who got off at Glória station neatly summed up. Having worked in various neighborhoods in the West Zone over the past five years, I have often heard this contrast being made between Rio's favelas and the West Zone. From interviews I conducted with residents from one community - which I shall not name in this paper, for reasons of anonymity - I learned that some of my interviewees were born in favelas de tráfico, or favelas dominated by drug gangs, and explained their decision to move to the West Zone with two different arguments: on the one hand, to escape from violence, and, on the other, to live better. Presidents of local residents' associations subscribe to these arguments, while presenting themselves as guarantors of tranquility and as the people responsible for achieving the progress that local residents can now enjoy.

This paper examines political and urban sociability in one área de milícia, or 'militia-controlled area.'5 What do residents and association leaders mean by tranquility and progress? To which space of experiences and horizons of expectation (Koselleck, 2006) does this other mode of urban sociability refer, namely, far away from violence? How are power relations organized and institutionalized so as to secure such tranquility and progress?

\footnotetext{
1 My thanks for the peer review assessments and the comments received from Adriana Vianna, Gabriel Feltran and researchers at NaMargem - Núcleo de Pesquisas Urbanas of UFSCar, in a seminar during which the first version of this paper was presented, and those made by my supervisor, Professor Luiz Antonio Machado da Silva.

2 Campo Grande is one the largest neighborhoods in the West Zone.

3 All words and expressions in italics are native categories. Double quotes transcribe phrases and opinions collected during fieldwork. Simple quotes are used to provide explanations of the social meanings of the words.

4 In my fieldwork, the idea conveyed by the word tranquilidade is hard to translate. I have opted to use 'tranquility' in this paper, but should stress the sense of easiness that the colloquial expression "é tranquilo" expresses in Portuguese. The social meaning of this 'tranquility,' or easiness, will be examined further on in this paper.

5 Milícias (militias) have a specific meaning in Rio de Janeiro. The term was coined by the media around 2006 to refer to groups of police officers and firefighters charging fees from residents in the West Zone for protection against drug dealers. Thus, áreas de milícia, or militia-controlled areas, are specific territories in the city. Since these are native categories, I chose to keep the Portuguese words: milícias, áreas de milícia and milicianos.
} 
In this paper, my methodological strategy will proceed along two lines: first, I present the experience of a family residing in an área de milícia, which I shall not identify. Though born in the region and not having personally experienced the escape from violence, the history of Seu Paulo' ${ }^{6}$ house $^{7}$ is particularly illuminating of the process through which communities emerge and become consolidated in the vast but as yet sparsely studied West Zone of Rio de Janeiro. Seu Paulo is one of the first settlers of the land where the community was progressively built, and maintains firm political ties with the top leader of the locale - the padrinho ${ }^{8}$ - who is named in the report produced by the CPI das Milícias ${ }^{9}$ (the Rio de Janeiro Legislative Assembly's Parliamentary Inquiry Commission on Militias).

To retrace the relations between the house and the city, I draw inspiration from the research by Mariana Cavalcanti (2007) on the consolidation of Rio's favelas. According to her, the territorialization of drug trafficking was juxtaposed with urban interventions during the 1980s and 1990s, decades in which urban planners hoped that access to urban infrastructure would help tackle poverty and thus reduce crime rates. As I shall argue, urban policies also played an important role in the shaping of áreas de milícia, but under different arrangements and justifications. I intend to reconstruct the aforementioned house's history by focusing on some problematic situations faced by Seu Paulo during his life. Here I explore how the disruption of future plans affects everyday life (Schutz, 1974). My main question in this first part of the paper is: how do urban policies and public works affect the residents' present space of experiences and their horizons of possibilities (Koselleck, 2006)?

In the second part of the paper, I shall describe the values and practices of the association presidents whom I had the chance to interview. Here my key inspiration is the highly praised paper by Machado da Silva (2011 [1967]) on power relations in favelas. I intend to answer the two main questions raised by the author in this work: what are the resources and markets controlled by these residents' associations? And what supralocal actors are they tied to?

Before proceeding to the substantial content of this paper, I should explain the methodology used. The research available on milicianos includes analyses of the CPI das Milícias report and interviews with state authorities involved in the combat against such groups (Werneck, 2015), as well as semi-structured interviews with residents of áreas de milícia, plus the analysis of Disque Denúncia (a police hotline) records and newspaper articles (Cano \& Ioot, 2008; Cano \& Duarte, 2012). In the wake of many urban policies, the volume of qualitative research conducted at various localities in the West Zone has grown in recent years (Brito, 2012; Siqueira, 2013; Gifalli, 2015; Dias, 2016; Gomes, 2016). As far as I know, though, these scholars have focused on a variety of issues, from Pacifying Police Units ${ }^{10}$ to recent land use and social movements, but none of them seems to have interviewed the milicianos themselves.

6 All real names have been changed in the paper. 'Seu' is the colloquial short form of 'Senhor,' or sir.

7 Following Janet Carsten \& Stephen Hugh-Jones (1995) and Eugênia Motta (2014), I use 'house' rather than 'household' in reference to domestic units so as to stress the living process between persons and their houses.

8 As I shall retain the anonymity of the man who figures in the CPI das Milícias, I hereafter refer to him as 'padrinho,' which is how community leaders in the region call him. I prefer not to use the English word 'godfather' to avoid impressionistic depictions of this political actor as the godfather in Francis Coppola's trilogy on the Italian-American mafia. In Brazil, the political ties between a consolidated actor and a novice are expressed as a godfather-godchild relation.

9 In 2008, the kidnapping and torture of journalists from the ODia newspaper, conducting an investigation on favelas without traffic, was widely reported in the media. This appalling situation drew public attention to milicianos, which was how the media dubbed the political actors in effective control of these areas. The same year, a Parliamentary Inquiry Commission was set up by the Rio de Janeiro State Legislative Assembly, with the purpose of investigating the support bases for these groups and how they exercised their domination. After publication of the subsequent CPI Report, a number of parliamentarians and presidents of West Zone residents' associations were arrested.

10 Unidades de Polícia Pacificadora, or Pacifying Police Units, were a security program created in 2008, in Rio de Janeiro. Military police forces permanently occupied dozens of favelas in the city. As the secretary of public security stated back at the beginning of the program, its intention was not to end the drug dealing, but to reduce the display of firearms and use of violence in the occupied territories. After the Summer Olympic Games in 2016 and amid the ongoing economic crisis in Rio de Janeiro State, the UPP program has been progressively dismantled. 
Having participated in the implementation of two urban policies in the West Zone, I had the opportunity to talk to milicianos and persons connected to them. Between 2012 and 2013, I had my first professional experience writing a social diagnosis on eight communities (again left unnamed here). My second participation in urban policy implementation in the West Zone was assessing the impact of public works over dozens of communities and middle-class condominiums.

In both experiences, I found myself in a rather ambiguous position. For most of the local population, my identity as a researcher, or sociologist, explained very little, notwithstanding the fact that I always introduced myself as such. Since these were work-related positions linked to public policies, my colleagues and I were acting "as the State"11 in the eyes of local residents and association presidents. Since residents are afraid to give interviews and residents' associations are rather mistrusting of any outside actors, the government identity proved pivotal. The importance of such institutional belonging became particularly clear to me in one interview. The interviewee seemed very uncomfortable talking to me and my colleague, as she feared we represented some non-governmental organization. I produced my UERJ doctoral student ID and repeated that I was doing research on the community's history. The [female] president of the local residents' association, who accompanied the first woman, tried to put her at ease by saying that "we were from the governmental program." Tapping into my institutional position, I added that we had already interviewed the padrinho, the top community leader of the region. Both items of information finally reassured my interviewee and she started talking about everyday life in the community. 'Being from a project' is a particularly negative identity in the West Zone, and 'being a university researcher' is not exactly sufficient to gain the locals' trust. Being associated with a public policy, however, allowed me to be assimilated as someone potentially powerful and capable of bringing improvements to the communities.

\section{The works and the progress}

As part of our assessment of the public works' impacts, my colleagues and I were faced with a big problem: how to oversee the removal ${ }^{12}$ of a community. The community's front area was where most of the local commerce was concentrated. The rear area was located next to the river, into which raw sewage from the houses was discharged. We strove to talk to the largest possible number of residents, so as to better understand the impasses brought about by the construction works. We discovered a rather complex universe, with multiple internal divisions: residents who had been compensated; others removed and relocated to apartments in various popular condominiums built as part of the Minha Casa Minha Vida (My House My Life) ${ }^{13}$ federal housing program; others residing along the river bank and who did not want to

11 I examined the complexity of meanings contained in this expression in my MA dissertation (Araujo Silva, 2013). Even considering that the experience of community work is very distinct from our own - precisely because their actions "as [representatives of the] State" merge with their condition "as [a local] residents" - the dilemma of possessing a 'double personality' is similar, to some extent. A community worker and friend of mine once told me that I should assume my 'double personality,' as I was both associated with the university and with social projects at the same time. Over the period in which I researched and engaged in favela movements, in favelas de tráfico, I got to understand the approximations between the two roles, "being from the university" and "being from a project": the understanding, the action and the criticism, the engaged production of information, etc. From the moment I went to study and work in the West Zone, I had to rethink the relation I would be able to create between my 'two personalities.' If, on one hand, NGOs and social projects are not favorably regarded by local political institutions, on the other hand, working for public policy programs opens doors for interlocution.

12 'Removal' and 'compensation' are native categories used by both the public administration and local residents. 'Removal' is a rather controversial term, only used in specific situations to express arbitrary and even authoritarian interventions. Not all changes of address are regarded as desirable and only in those cases do residents use the term 'removal.' But this meaning is not consensual among residents, many of whom share with public managers and technicians the understanding that their dwellings are indeed precarious and should be the object of intervention. I have written about the different narratives used with regard to moving to Minha Casa Minha Vida housing projects elsewhere (Araujo Silva, 2016, Araujo Silva 2017). 'Compensation' equally contains a specific meaning. Monetary compensations for the lost houses do not accompany market values, but a specific price list devised by City Hall, unavailable even to community workers responsible for the negotiations with residents. House valuation criteria include build quality and refurbishments or improvements. Its location in the city is not considered, even though this is a crucial criterion from the point of view of the local informal real estate market.

13 The Minha Casa Minha Vida housing program was created by the federal government in 2009 with the purpose of resolving Brazil's housing deficit. It provides for the production of housing units to three income ranges historically excluded from the country's formal real estate market: families with incomes from o to 3,3 to 6 and 6 to 10 minimum wages. 
leave their homes; others living in kitchenettes ${ }^{14}$ and anxious to change address; others owning large houses and desperate to stay in the place where they had been living for nearly thirty years.

The construction works were causing long-term neighbors to oppose each other, and we were prevented from listening to all of them with equal respect: we had to choose a side or else risk generating mistrust. For the purposes of our diagnosis, this problem imposed the challenge of depicting such conflicts in all their complexity, without minimizing the insecurity and anxiety experienced by all these residents, willing or not to leave the community. As far as possible, we tried to listen to residents who were not members of the local association, as well as to association directors. In another paper (Araujo Silva, 2016), I focused on conflicts arising from the announcement of an impending removal in a North Zone favela condemned as a risk area. ${ }^{15}$ Continuing my reflections on the paradoxes of the housing issue, here I elect to narrate the story of a long time resident of the threatened community (later partially removed) with the intention of enabling a deeper understanding of the political and economic dynamics at work in the West Zone. By no means does such a perspective intend to overlook the struggles carried out by other groups; it is just one of the possible approaches to the problem.

Seu Paulo was born 60 years ago on a sitio, or ranch. At the age of 18 , soon after marrying for the first time, he bought his first house from a coworker. It was "very shabby, a meia água [a small mono-pitched dwelling]" located "in a horrible place" in the neighborhood of Vilar dos Teles, in the municipality of São João de Meriti, Baixada Fluminense (Rio de Janeiro State's flat lowlands). At the time, Seu Paulo was already a carpenter and worked on the construction site of BNDES' (Brazil's National Social and Economic Development Bank) club, in Barra da Tijuca. Some years later, he found someone 'crazy' enough to buy his meia água, and used the money to passar- transfer into his name ${ }^{16}$ - an apartment.

In the mid-1980s, as he was divorcing his first wife, Seu Paulo began looking for another place to live. On a bus returning to his apartment after work, he learned about a land occupation. He saw some barracas, plastic tents, erected on a vacant lot. He decided to join the occupants, therefore, so as to get his own pedacinho de chão, 'little piece of ground.' Seu Paulo introduced himself to Dona Simone and Seu Noel, the occupation's organizers. "We've come here with the intention of having a better life," "obtaining the lotes, the plots of parceled land, to build a decent community on it. ${ }^{{ }_{17}}$

At the company where he worked, there was a print shop where "based on friendship with poor people like himself," Seu Paulo arranged for the ID cards of the land occupants to be printed for free. In possession of the list of those registered to claim ownership of those lots, Dona Simone, Seu Noel and Seu Paulo founded a residents' association and registered it with the Federation of Favelas of Rio de Janeiro (FAFERJ). "Everything was done according to the law." Since these were the years of Brazil's redemocratization and the Constituent Assembly, they considered baptizing the new community 'New Republic' or 'Tancredo Neves' - in honor of Brazil's first civil president after the military regime, who died just before taking office. They eventually decided to choose a name that would stand as a symbol of union, which I will keep undisclosed. After registering with FAFERJ, the residents' association obtained the inclusion of the new community in

\footnotetext{
14 The terms 'casas' (houses), 'quitinetes' (kitchenettes), 'apartamentos' (apartments) and 'unidades habitacionais' (housing units) should be seen as native categories given that, despite being broadly used, they obey a certain social hierarchy. 'Housing units' is a category used by the public administration. 'Apartments' are seen as small, low-standard places to live in, where residents' "building imagination" (Cavalcanti, 2007) cannot be explored. On the other hand, a 'house' is not just any constructed dwelling since there are various 'modalities of living': kitchenettes - very small places, often lacking windows and bathrooms; shacks - poor self-built, wooden constructions; tiny, but decent houses, large houses and fortresses. As we shall see further on in this paper, there are a variety of modes of dwelling among the poorer classes, and we need to take into consideration the qualifications specifically ascribed by the latter to each mode, so as to understand housing trajectories and the related perceptions of living better.

15 'Risk area' is a technical expression that denotes areas prone to geological accidents, such as landslides and flooding.

16 'Passar,' to pass or transfer to someone's name, is a very common practice among the working classes. It refers to the economic transaction of selling a house to someone else, without fulfilling legal procedures.

17 During his narrative, Seu Paulo oscillates between saying that the terrain was idle and that it was parceled land.
} 
the list of beneficiaries of the Meu pé de chão (My piece of ground) project, run by the Municipal Secretariat for Social Development, under which the possession of land lots was recognized.

Amid the proceedings to formalize the newly created community, Seu Paulo transformed his original barraca, plastic tent into a barraco, a shack. He leveled and compacted the portion of land that fell to him, fixed wooden stakes around the perimeter and made a roof for himself and his second wife. The daughter they had together was born in this shack, their home before completion of the casa, house, which Seu Paulo was building little by little, "until making it a decent home." He never pulled the shack down, since he considered it to be a forma de viver, a 'form of living,' and, after moving to the house, leased the dwelling out, thus complementing his income as a carpenter. The house took years to be finished as it depended on him having free time available to work on it, or on money to pay somebody else to do the jobs.

Seu Paulo built his house with great care, and was very proud of it. To him, someone who "always felt a social outcast," having his own brick house was quite a victory. To symbolize this achievement, he chose a rather unique decoration: a vine design for the wooden front door and tilting windows in the kitchen. The first time I went to visit him, he made a point of showing off his aesthetic preferences and the real vines he had planted in the open terrain. Every December he throws a grape party, inviting community children to eat the fruits from the latest harvest and to drink fresh juice. "Why vines?" I asked him. "Because they're symbols of prosperity for the Portuguese people." He had learned about this symbolism back in Vilar dos Teles, from his meia água neighbor, a housemaid who worked for a Portuguese woman to whom Seu Paulo rendered services for decades. "A dream has no price, we make it come true." Contrasting with his past life as a suffering worker, a house surrounded by prosperity, the accomplishment of progress in his life.

In the 200os, Seu Paulo divorced his second wife. Sometime later he started dating a tenant who was living in one of his two shacks - he had split the original one in two for rental. In 2012, the couple faced a major challenge: rumors began to spread, indicating that the entire community where they lived would be soon removed to give way to public works. Seu Paulo joined the trenches of the resistance.

In late 2013, the community's front portion was cleared. Residents were presented with two options: removal to Minha Casa Minha Vida apartments, or compensation for their houses. To owners of small businesses, however, no alternative was offered to make up for the loss of their workplaces. As demolitions were in progress and people were moving out, another rumor spread that some of the houses had been compensated for at market values, causing great commotion. In parallel, as an independent state intervention, the rear area of the community, alongside the river, was marcada para remoção, marked for removal, as the entire site had been condemned as a risk area. Some residents wanted to move to apartments, others wished to stay, others still wanted to receive cash compensations. The tumult led to a collective outrage, adding to the ongoing conflict.

A number of residents started subdividing their houses into as many housing units as possible, taking into consideration City Hall's criteria for determining compensations..$^{18}$ Others started building kitchenettes on their lajes (flat cement slab roof tops) or in backyards. Tenants were evicted so that houses and kitchenettes could be passed on to the owner's relatives. Purchase and sale transactions were on the rise, as well as prices, with everyone trying to deal with the situation the best way possible. Those who paid rent could invest in the purchase of a kitchenette, betting that it would be marked for removal and then exchanged for a two-bedroom apartment in a popular condominium. Newly-weds could squeeze for a time into a puxadinho, little house annexed to a larger one, expecting to be removed and thus getting to leave the community. Those wishing to move out envisaged the possibility of receiving compensation with which

18 From the architectural point of view, a house is formed by walls and an independent hearth. The tactic of building walls and buying stoves was designed to convert the house into as many households as possible. The purposes might vary from expanding one's property to providing relatives with houses of their own. 
they could buy another house elsewhere. Situations were multiple. Opportunities, however, were not so many. It was not known for sure who had the right to compensation, and rumors alluded to those with better political contacts.

Seu Paulo's two shacks on the river bank were marked for removal. He transferred ownership of one of them to his girlfriend (today his third wife), and the other to one of his sons. When the apartments they would receive in exchange were sorteados (drawn), ${ }^{19}$ Seu Paulo took their family to a barbecue restaurant to celebrate. Later he and his wife started buying tiles and 'small furniture' that would fit the apartment's small floor area. They were determined to turn that "crummy apartment, a tiny thing" into a new home.

The marking of houses for clearance along the river bank heightened the tension in the community. Seu Paulo developed strategies for the impending removal of his house. First he researched the real estate market in his neighborhood, looking for "houses of equal value to his own," to present as a parameter to City Hall. Should they really decide to remove his house, he would know how much he should press for as compensation. "Each one knows how much their house is worth, each drop of sweat, each brick they laid," said Vilma, the association's president. Seu Paulo thought his house should be priced at $\mathrm{R} \$ 200,000$ or $\mathrm{R} \$ 300,000$. As a complimentary tactic, he quitted his job and used his severance pay to construct three kitchenettes on his house's laje (cement roof). He also bought a residential lot in a loteamento, parceled land in Jardim Maravilha, an area of Guaratiba, located in the extreme west of Rio. He intended to rent them out to make some money while waiting for his house to be removed.

As the months went by, conflicts within the community were only getting worse. Over time, hearsay about compensations and the prospect of exchanging small, lousy houses and kitchenettes for $42 \mathrm{~m}$ twobedroom apartments led residents to change sides. According to Seu Paulo, the number of "minds set on profiteering" were on the rise. Grileiros, ${ }^{20}$ land grabbers, "constructors of matchbox houses," had their eyes on the apartments. Needless to say, he did not include himself in the latter group. To him and other members of the association's board, residents have the right to build their living quarters as they wish. What differentiates grileiros from cabeças boas - literally 'good heads,' well-intentioned, mindful people - is the use made of the houses built. "Passing them on to relatives is legitimate," whereas "selling kitchenettes is grilagem."

The whole of 2014 and the first half of 2015 witnessed political turmoil. The community split in two: those who had a 'good, decent house' and who wished to stay, versus those who had a small house, a 'matchbox' and wished for better; "the old ones, who struggled," who "came up from the ground" against "the young who had never stepped on mud, had never built anything"; "democrats in favor of the collectivity" as opposed to "the violent, manipulative, individualistic people." Amid all the gossip and some physical fights, another group of residents was removed to a Minha Casa Minha Vida condominium, fitted with a swimming pool, a large slide for kids and lifeguards, paid for by the municipality. Vilma, the association's president, was one of the beneficiaries. "In recognition for her work," a resident passed a kitchenette to her name, a "blessing in her life." A single mother with two teenage kids, she could finally leave her own mother's home. She became the sindica, the manager of the apartment block where she went to live in.

\footnotetext{
19 Minha Casa Minha Vida apartments are sorteados, 'drawn,' as follows: first, families included in the social register filed by the municipality's community workers are listed in order of priority, according to criteria that may vary from one city to another. As the developers deliver the low-income condominiums, applicants at the top of the list kept by the Municipal Housing Secretariat are drawn first so as to determine to which condominium they are to be resettled. When the list of residents per condominium has been exhausted, a new draw begins to define which apartments go to whom.

20 The Portuguese term used - grilagem - refers to the act of forging title deeds so as to claim land ownership.
} 
Pressure was piled on City Hall until eventually the construction site was relocated. For Seu Paulo, the day that this was finally decided at the headquarters of the local samba school was "the happiest day of his life." In his words, they "turned a page of History." Not only would they remain in the houses they had built for themselves, they would also benefit from the public facility - which they had so fiercely fought against nearby. This was a victory of progress.

That same day was one of frustrated projects for other families. The community was reduced from 800 to 200 houses, big families were moved to small-size apartments in faraway low-income condominiums, businesses were destroyed. In the view of Vilma, the association president, those outraged had attempted 'abuses' during the process. One man had demanded compensation for a cantinho de bagulhos, a tiny scrap shed; a woman had claimed that she had been left without her workplace, since her house was also her couture workshop; many blamed City Hall for cracks and seepage, allegedly caused by the construction works. Vilma argued that those who "speak ill of the City Hall" are lying, given that "everybody profited." The problem for Vilma, Seu Paulo and Dona Simone was that people fail to understand that "the City Hall is no Santa Claus, nor a shop, nor a real estate agent." "There's no impeding progress," said Dona Simone.

In the 2016 municipal elections, Seu Paulo, Dona Simone and Vilma intended to campaign for Pedro Paulo, the candidate of then Mayor Eduardo Paes, known to locals ever since he had been subprefect of Barra da Tijuca. "My house is open to him, whenever he wants," said Seu Paulo.

\section{The political bases of tranquility and progress}

Rio's West Zone is the largest geographical area of the city. Nonetheless, it is also its least studied region when it comes to social science research. There are numerous political and urban spatial arrangements within the West Zone: Barra da Tijuca and its gated communities; the districts spreading alongside the Santa Cruz train line; the neighborhoods along the west seashore; the municipality's geographical limits, where the borders between rural and urban are still negotiated. There are circuits of power creating social networks linking geographically distant districts, and connecting some of these to the Baixada Fluminense. Despite all this diversity, among those who live in the Central, South and North zones, representation of the West has been crystallized as a vast area of irregular loteamentos and áreas de milícia.

Notwithstanding (or perhaps due to?) its ranking as the region with the highest concentration of autos de resistência (police killings) ${ }^{21}$ in the city (Misse et al. 2013), local residents are almost unanimous in their appraisal that the West Zone is an easy place to live, in clear contrast to Rio's image as a violent city. It is precisely this tranquility that is thematized in the anecdotal conversation that opened this article. But what exactly ensures this sensation of tranquility, in a city where sociability is marked by a diffuse fear?

The community where Seu Paulo lives is located in an área de milícia. Dona Simone, Vilma and he reject the label, but a number of other residents and members of rival associations refer to both the padrinho and to association presidents subordinate to him as milicianos.

I had the opportunity to meet the padrinho, the miliciano in charge of two dozen residents' associations, in both my professional experiences in the West Zone. In 2015, we scheduled an interview. My colleagues and I waited for 30 minutes for the padrinho to arrive at the association he presided, as he had arranged with us. A big man - over $1.9 \mathrm{~m}$ tall - white, strongly built, wearing shorts and slippers, he began by apologizing for his delay, explaining that he had been solving some "community issues", which he did not specify.

21 Auto de resistência is an administrative category used to classify deaths caused by police officers in the line of duty. It is a highly controversial one, because the authorship of the killing is self-declared by the police officer, but his or her motivation is presumed to be legal even before trial. As Misse and al. (2013) show, autos de resistência reports and figures are fabricated following a crystallized pattern: the scene where the alleged clash took place is pinpointed in favelas, the opponent is portrayed as a violent drug dealer, and the police action is reported as having been a response to coming under attack. 
On the building's second floor, in a large room fitted with a long wooden table placed in the corner, near the window, with a sofa, shelves and files on the opposite side, he sat on a high-backed wooden chair facing three flags: those of Brazil, Rio de Janeiro State and the 'samba school' of which he is the patron. Before we started explaining to him what our assessment of the construction works revolved around, Anderson ${ }^{22}$, whom we had already interviewed, knocked at the door. They talked for less than two minutes about some pending issues and, on leaving, Anderson thanked his padrinho for his attention, kissed him on the forehead, and left.

I had already witnessed a rather similar hand-kissing ritual before, in an assembly held to discuss urban planning for the region, during my first professional experience there. On the occasion, all eight association presidents approached the padrinho to greet him as soon as he arrived. Various of them had taken up their institutional positions as presidents in the wake of government interventions. Some of the areas that we mapped and diagnosed began to organize politically so that residents could benefit from the planned urban investments. The newly constituted associations had no headquarters, and their presidents had no previous political experience whatsoever. Each had a distinct life story: some were shopkeepers, others were older residents, others still worked at local social service centers. What they did have in common was their subordination to the padrinho, whom they had as their political mentor.

These scenes and stories are indeed relevant, as evidence of political authority enjoyed by the padrinho, specially vis-à-vis actors invested with public identities. It is rather unlikely that such hand-kissing would be repeated in such a fashion in local daily life. But since these were occasions during which urban programs were being publicly discussed, it seemed to be important as a means to highlight the padrinho's political superiority. Meetings, assemblies and interviews become social dramas in which local political arrangements are enacted before an audience made up of external actors. Thus, while publicizing the political protagonism of the padrinho, the associations presidents would confirm political subordination to him.

Recounting his own story, the padrinho told us he was born on a sitio, or ranch, in what was then still a rural zone, in the late 1950s, of a Portuguese mother and a peasant father. In the beginning of the 1980 s, a parliamentarian who had the padrinho's neighborhood as a constituency procured him land to parcel out. The padrinho then led mutirões - collective work rallies to build housing and infrastructure - to turn the vacant lands into habitable lots. With funding from the Municipal Secretariat for Social Development (SMDS), he provided "a mortadela, a cachaça e o mocoto" (plentiful eating and drinking) to pull residents together and build sewage disposal systems and street lighting for the lots. He was also the one to press for title deeds under the Meu pé de chão municipal program.

\footnotetext{
22 Among the dozen of community leaders under the padrinho's control, Anderson is an interesting case. President of one residents' association and a board member in another, he described a trajectory parallel to - and over time, intertwined with - that of the padrinho. Born in Rio's low-middle class neighborhood of Madureira, his family used to live in a rented place in a favela de tráfico. In the mid-199os, an uncle - a military man - told his father about loteamentos in a neighborhood in the West Zone. In the late 199os, already by then in his early twenties, Anderson became a cabo eleitoral, a campaigner for political candidates, an activity for which he received $\mathrm{R} \$ 500$. After the election period, he got a position at the community radio station owned by the parliamentarian for whom he had campaigned. Later this same politician introduced him to the padrinho, a prominent, self-proclaimed community leader. Through this city councilor, Anderson managed to obtain street lighting for his community. During Governor Anthony Garotinho's administration, the Assembleia de Deus Vitória em Cristo congregation, led by pastor Silas Malafaia, took over distribution of the cheque cidadão, citizen check - an income supplementation program - in the communities under the padrinho's rule. As a member of the church, Anderson took control of the register of beneficiaries. Later on, he led the church's campanha do quilo (a food donation and redistribution campaign). During his interview, he expressed his hope that the urban facility we were assessing "would one day make him a city councilor," thus making it explicit that he would once again capitalize politically on the improvements brought about by social and urban programs. Despite having accumulated political contacts and resources of his own, Anderson became the association president only thanks to the padrinho's support.
} 
In addition to parceling the land, the padrinho also set up residents' associations subordinate to him. This is the other side of the story told by Seu Paulo. The occupation organized by Seu Paulo and Dona Simone was already being led by the padrinho, with the support of a parliamentarian who pressured the SMDS to include the occupants in the list of Meu pé de chão's beneficiaries. The affiliates' ID cards, which Seu Paulo had been able to print at the company for which he worked, sealed a political alliance with the padrinho, who gave his political blessing to him and Dona Simone to found the new community's residents' association.

On one hand, funding the mutirões enabled the padrinho to organize the occupation of various portions of land. On the other, recruiting management board members from among the more strongly committed land occupants allowed him to build a political network around himself, which strengthened his position vis-à-vis external interlocutors.

Strongly personalistic, the padrinho claims to be responsible for all the progress, "improvements for the communities": pavement, asphalt, lighting and sewers. ${ }^{23}$ In a West Zone area marked by conspicuously scarce urban infrastructure, public works and equipment are important political resources. In exchange for them, the padrinho and other association presidents expect gratitude expressed in votes. As he said during our 2015 interview, he had already "helped to elect a lot of politicians" but, unfortunately, "residents do not always show recognition for the association's work" and so fail to vote for candidates from their own areas. The padrinho himself, despite possessing some twenty associations under his control, has run more than once as a candidate for legislative positions but has never been elected. So, the padrinho remains dependent on elected politicians whose constituency includes his neighborhood, without ever rising to higher positions himself.

Control of access to the land and to public equipment does not differentiate in any sense the power exercised by the padrinho and his network of residents' associations. As Machado da Silva wrote back in 1967, the political force of residents' associations in favelas relied on the control of economic resources such as lighting and water pipes, as well as the local real estate market. Under the padrinho's rule, security provision is the truly distinctive factor. But here too it is necessary to specify the difference between rendering 'security services' - which allows us to speak of a milícia - from other modes of providing protection. Since the beginning of the 1980s, drug dealers have also regulated the favelas where they carry out their business, but they do not charge for doing so. In her classic work A máquina e a revolta (The machine and the rebellion), Alba Zaluar (1985) highlighted the role of bandidos (bandits) turned into local vigilantes (vigilants) in Cidade de Deus - one of the city's most notorious favelas.

We explicitly asked the padrinho and all the association presidents who we interviewed whether there were milícias in their neighborhood. "No, the milícias are over there in Campo Grande. This here is a police area." Pointing to the surrounding houses, Anderson indicated where a Pacifying Police Unit policeman lived, and the home of another policeman with the Bope (Special Operations Battalion), and that of a civil police officer, and still another from the $22^{\text {nd }}$ Military Police Battalion. After the $2008 \mathrm{CPI}$, the term 'miliciano' - as might be expected - became the target of accusations and public rejection.

Precisely to counter this stigma, apparent legality is particularly valued by the padrinho and by the association presidents connected to him. During his interview, the padrinho made a point of showing myself and my colleagues a huge pile of maps, minutes, receipts and records, while stressing that all his staff were duly registered employees and received pay above the official minimum wage.

23 A more extensive mapping of such services still remains to be carried out, since they vary from one community to another. In Seu Paulo's community, gas fitting was not carried out by the residents' association, since it was the monopoly of one particular resident who - relying on his public image as someone who "renders services to the community" - took a chance and ran as a candidate for the state legislature, but lost. In other communities I got to know, van transportation is monopolized by local coops, which pay fees to the local association in order to operate. 
This producing of documents was explicitly intended to situate his business in the security market, along with private enterprises that have been prospering from this booming business in Brazil since the 1990 (Paixão, 1991). Research still needs to be done on the private security market in Rio. Zanetic (2005) and Cubas (2002) have analyzed the privatization process of public security in recent years in São Paulo. The $75 \%$ increase in the number of security enterprises between 2002 and 2016, according to one survey conducted by Agência Pública journalists, ${ }^{24}$ indicate that this market niche is expanding significantly.

We can turn to examine what the padrinho had to say about his business. He relied on his authority as a military policeman to control the access of local families to land. In 1981, he became a private in the military police, after having been a peddler and street vendor for some time. He proudly admits having taken part of the "glorious esquadrão da morte (death squad)"25 that took care of 'their square' of city. The method was: "no tolerance towards vagabundos," as bandits, specially drug dealers, are referred to. This is the crux of the matter.

The padrinho presents himself as a 'keeper of public order,' making judgments and exerting his power over those living in the area under his control. He gives coças, 'thrashings,' here and there, throws garbage left on the sidewalk back inside people's houses, and shouts about and judges the behavior of those whom he allowed to acquire a piece of land in the region. Today, the padrinho says, "many a family man will thank me for having received a thrashing from me." It was not just anyone he would be willing to correct, but only locals who displayed inadequate behavior, namely, "northeasterners, drunkards, pigs, persons without hygiene, negligent mothers." The "vagabundos dealing in drug traffic," like those in Cidade de Deus (an area previously patrolled by the padrinho for his police battalion), these he never "pestered". In his opinion, if those vagabundos exist, it is their 'mother's fault' - for a lack of someone like himself to give them some thrashing. They are not his problem.

As Cardoso de Oliveira (2008) rightly underlined, not every use of force is understood as violence, only those forms involving moral aggression. Cases of thrashings are good as food for thought, since they are intended to teach a moral lesson. They are certainly punishment for condemned acts, but are not devoid of consideração, esteem for the other. Much to the contrary, they purport to shape the character of whoever is being beaten, and in that sense are understood as a duty performed by the aggressor. So, as the padrinho stated, the thrashings could even be grounds for gratefulness. Just as killings in favelas de tráfico are not judged a priori to be crimes (Zaluar, 1985), or even errado, 'wrong' (Grillo, 2013), but are, rather, situationally differentiated depending on whom and under which circumstances one kills, so too in áreas de milícia aggressions are understood as corrective thrashings, or else as torture, depending on perpetrator and recipient. Likewise, murder is alternatively seen either as wickedness - when committed against residents who could not pay the 'fees' - or as justifiable homicides, in the case of "them there fights" among connected persons. ${ }^{26}$

Just like many others running security enterprise, ${ }^{27}$ the padrinho is a former police officer who sells protection for fixed prices ( $\mathrm{R} \$ 9,50$ for residents, $\mathrm{R} \$ 20$ for businesses per week). What makes the milícias so singular is that, as Misse has accurately pointed out, they operate a political market (Misse, 2011), in which the economic value of the commodity being traded relies on the privatization of the State monopoly on the use of force.

\footnotetext{
24 https:||apublica.org/2017/03/uma-em-cada-quatro-empresas-de-seguranca-em-sao-paulo-e-ligada-a-policiais|

25 Esquadrões da morte date back to the 1950s when special police units were first created to patrol Rio, then the capital of the country. Their official name was Esquadrões Motorizados, or motorized squads. Because the policemen in those squads used to leave notes signed with 'E.M.' by the corpses they left behind, they came to be dubbed Esquadrões da Morte, or death squads. For further information on esquadrões da morte, see Misse (1999).

26 In the West Zone and also in some places of Baixada Fluminense, the expression 'being connected' is used to refer to relations with the milícia. In favelas de tráfico, though, the expression used is 'being involved' [with the drug gangs].

27 Zanetic (2005) shows that security enterprises offer bicos, informal job opportunities for police officers.
} 
Furthermore, the milicianos have the prerogative of using force against those who buy their services, which it is not the case with security enterprises. Such an arrangement allows us to speak of a political order to which residents submit. Among association presidents, the padrinho evokes the idea and embodies the value of ordem (order). Among residents, though, there is no such consensual approval of his power. Many of them are afraid and will not talk openly about the residents' associations. They comply with their rules, nonetheless, since they regard the West Zone as an ease place to live. Shots irrupt occasionally, and many assassinations of persons with connections take place, but, by paying the taxas de seguranças (security charges) regularly, they believe it is possible to keep violence away from themselves and their families.

A crucial resource in maintaining submission is fear. Not directly of the padrinho, though this also exists, but of invasions by drug traffickers. Rumors that drug gangs are planning to invade the area are recurrent, and shape local residents' horizon of expectations. Any conflict or use of force immediately places locals on red alert for potential attempts at invasion. There is a shared perception that 'the traffic' are always on the lookout for opportunities to expand their drug business. Numerous cases of use of force, outbursts of shooting and assassinations are initially seen as a threat of invasion.

Understanding this desire to keep a distance from violence is crucial to understanding the submission to milícias in Rio's West Zone. This distance from violence becomes socially constructed through trocas de ideias, 'exchanges of ideas,' (Zaluar, 1985) and rumors (Menezes, 2015), ${ }^{28}$ thereby ensuring some prospect of temporal continuity of life, the basis on which ontological security (Giddens, 2003) can be maintained and plans for the future made. Violence happens elsewhere; the use of force is justified; the drug business is distant.

My argument is that the exercise of power by milicianos does not rely on a shared value. However, it would be inexact to say that they are simply illegitimate authorities in the weberian sense since their exercise of power is fairly stabilized - they maintain a strong administrative apparatus and do indeed count on effective obedience. The heart of the matter, in my view, is twofold: on one hand, force is concentrated in the hands of the milicianos, given that they are connected to the official public security apparatus and rely on numerous supralocal political contacts; on the other hand, they justify this concentration of force by reference to the ideology of fear that hovers over the city of Rio. I propose that the milícias be conceived as forced authorities. Their power is exercised on the basis of negative obedience, i.e., obedience fueled by a fear of living in fear - something that residents often express. Fear of the drug dealers' force is much stronger than that of the milícias' force, although in both cases it is qualitatively the same: namely, the fear of being killed. In this sense, the exterior fear - or fear of invasions by the traffic - is the key point on which the domination relation rests. The fear of living in fear is what persuades residents and business owners to paying taxas de segurança, security charges, even while not believing in the legitimacy of the padrinho's authority, and while being aware of their illegality.

In this West Zone area that I know better, therefore, the social boundaries of the área de milícia are delimited by the reach of the padrinho's power, materialized both by the provision of infrastructureditches, cesspits, street lighting, and so on - and by the security market monopoly. ${ }^{29}$ Direct control over the various locations comprising an área de milicia is delegated to residents' associations, of whose managing board the padrinho is invariably a member. This way, through a juxtaposition of land, services and security markets, on one hand, and an institutionalized political network, on the other, there emerges an área de milícia, as one more territory of Rio de Janeiro.

28 It would be of interest to conduct a research on rumors in áreas de milícia, following Palloma Menezes's thesis on the rumors surrounding pacification (2015). As far as configurations of violence are concerned, this could be a viable methodological strategy. However, it lies beyond the scope of this article.

29 This is a power configuration in which the miliciano is himself a resident police officer. In the area under study here, there was no militia entrance event. In other areas of Rio's West Zone, however, the milícia clashed with drug dealers for territorial control. In any case, the research hypothesis remains to be tested in other areas. 


\section{Final considerations}

In 2006, newspaper articles appeared expressing bewilderment at the existence of favelas without drug trafficking in the city of Rio de Janeiro. Groundbreaking research coordinated by Ignácio Cano and Carolina Ioot (2008) raised various hypotheses to try and explain the phenomenon. As this was just one year before the Pan-American Games, it was suspected that some of the city's favelas - especially those near the sporting venues, in Barra da Tijuca - were being targeted for dismantling of the local drug trafficking network. Another supplementary hypothesis pointed to the weakening of certain drug gangs. It was supposed that, over the years, the police had amassed enough information and knowledge on the organization and modus operandi of these factions to enable them to become the protagonists rather than just - as previously - the mediators of the crime world's political economy (Alves, 2008; Cano \& Ioot, 2008).

For the last decade, public debate has revolved around the legitimacy of the milícias' dominance. During his first campaign as a mayoral candidate, in 2008, the very same year when the CPI das Milícias was set up, Eduardo Paes caused indignation when he stated on television that the polícia mineira ${ }^{30}$ and local policemen had brought tranquility to Jacarepaguá. By interviewing residents living in áreas de milícia, Cano and fellow researchers first identified a discourse about a liberating crusade against drug trafficking (2008) and, later on, a discourse of order and regulation associated with protection against crime and uncertainty (2012). The padrinho mainly mobilizes this latter discourse.

In order to deepen our understanding of the way domination operates in áreas de milícia, I propose the further inclusion of urban policies in our considerations of the topic, as unanticipated vectors in the expansion of organized crime. The pioneering research conducted by Burgos (2002) sheds light on the importance of associative activities in shaping the milícia model, which later became known as the Liga da Justiça, 'Justice League,' and became the target for intensive repression after the CPI. According to the author, control over residents' associations had enabled the regulation of territorial occupation on the basis of traditional values of personalism and reciprocity - which also appeared in my own field. On this point, my contribution has sought to take into consideration the fact that residents' associations are key points of articulation between local and supralocal actors, as suggested by Machado da Silva (2011 [1967]). As I have sought to demonstrate, setting out from the padrinho's case, control of access to land and to improvements laid the foundations for the asymmetric exchanges established between policemen "as community leaders," "taking care of their own patch," and local residents.

Onto this mode of domination, so common in the favelas, a security market was superimposed. Based on the ideology of fear, some policemen acting "as community leaders" have created a new repertoire for the grammar of urban violence (Machado da Silva, 2010): the repertoire of tranquility, or distance from violence, which underpins the political market of protection against potential invasions by drug traffickers..$^{31}$

As highlighted by Cano \& Duarte (2012), the milícia should be understood as representing a relation of domination that forms part of a continuum extending all the way from a clientele relationship, based on the selling of private security, to vassalage imposed by extortion. Their interviewees' perceptions varied between these two poles. In this sense, we could think of the milícias as being part of a wider security market that expanded as a counterpart to drug trafficking and the generalized fear this caused to spread throughout the city in the 1990s. Paixão (1991) already warned about the growing security industry - legal and extralegal - and the challenges it would pose for the defense of human rights in Brazil.

30 Polícia mineira was a form of security provision in Rio in the 1970s. Some police officers and local vigilants would take justice into their own hands, beating, lynching and killing robbers. The term mineira refers to the act of mineirar, mining, whose metaphorical meaning is "separating the wheat from the chaff," or the good citizens from the malandros and vagabundos.

31 A recent initiative by Werneck (2015) seeks to understand how different social types - the drug dealer, the corrupt policeman, and the death squad killer - are combined in the construction of this "platypus of criminalization": the miliciano. This research corroborates the idea that the milicia should be conceived as part of the grammar of urban violence. 
Ever since then, the boundaries between legal and illegal have been becoming even more blurred than one could have assumed. On one hand, military policemen are doing bicos, odd jobs on the sideline as private security agents, or illegally charging businessmen for privileged protection in low and middle-class neighborhoods. On the other hand, the CPI ended up increasing miliciano's concern with issuing receipts and producing notes, records and other such documents.

When examining this branch of the security market, we cannot overlook the singularity of 'protection' as a political commodity. Misse (2011) has already stressed that its appreciation in the market varies according to prospective demand. ${ }^{22}$ The bigger the number of protection buyers, the higher the appraisal for security. As I have argued in this paper, urban policies ended up playing an unforeseen role in the creation, consolidation and expansion of such demand. By offering official recognition of land ownership, the Meu pé de chão program inadvertently gave the final push towards establishing the padrinho's control - while he was still in the esquadrão da morte, death squad - and enabled him to constitute residents' associations subordinate to him. Negotiations to procure public utilities, such as water supply networks, street lighting and road paving, further consolidated his position as a local protagonist articulated with supralocal actors - parliamentarians, secretaries and subprefects of Barra da Tijuca. Recent urban programs in which I worked lead to the emergence of some more associations and removals to popular condominiums, expanding the area under his control westwards.

The intertwining of urban policies with the security market, carving áreas de milícia into the urban tissue, is well captured by the interior design of the headquarters of the associations. Behind the desks of their presidents hangs a photo of the padrinho striking a pose in elegant attire, in front of which maps hand-drawn on brown paper show the communities' original lots.

Translated by Francisco Polatscheck

Revised by David Rodgers

Received: December 20, 2016; Approved: May 26, 2017

32 In contrast, drugs, for example, are appreciated in the market according to the costs of production and sale. 


\section{References}

ALVES, José Claudio Souza (ed.). 2008. "Milícias: mudanças na economia política do crime no Rio de Janeiro”. In: Justiça Global (ed.), Segurança, tráfico e milícia no Rio de Janeiro. Rio de Janeiro: Fundação Heinrich Boll. pp. 33-36.

ARAUJO SILVA, Marcella. 2013. A transformação da política na favela: um estudo de caso sobre os agentes comunitários. Dissertação de Mestrado. Programa de Pós-Graduação em Sociologia e Antropologia. Universidade Federal do Rio de Janeiro.

2016. "Entre as estatísticas e a cidade: o cadastramento e a produção da demanda social por apartamentos no PMCMV". Cadernos Metrópole, 18(35): 237-256.

. 2017. Obras, casas e contas: uma etnografia de problemas domésticos de trabalhadores urbanos, no Rio de Janeiro. Tese (Doutorado em Sociologia) - Instituto de Estudos Sociais e Políticos, Universidade do Estado do Rio de Janeiro, Rio de Janeiro.

BRITO, João Felipe Pereira. 2012. Terras Quentes Reinventadas: a criação do bairro Gericinó como parte de transformações urbanas do bairro Bangu. 138 p. Dissertação (Mestrado em Sociologia e Antropologia). Universidade Federal do Rio de Janeiro, Rio de Janeiro.

BURGOS, Marcelo. 2002. "Favela, cidade e cidadania em Rio das Pedras". In: Marcelo Baumann Burgos (ed.), A utopia da comunidade. Rio das Pedras, uma favela carioca. $1^{\text {a }}$ ed. Rio de Janeiro: PUC-Rio/ Loyola. pp. 21-91.

CANO, Ignacio; DUARTE, Thais. 2012. "No sapatinho" : a evolução das milícias no Rio de Janeiro (2008-2011). Rio de Janeiro: Fundação Heinrich Böll.

CANO, Ignacio; IOOT, Carolina. 2008. "Seis por meia dúzia? Um estudo exploratório do fenômeno das chamadas 'milícias' no Rio de Janeiro”. In: Justiça Global (ed.), Segurança, tráfico e milícia no Rio de Janeiro. Rio de Janeiro: Fundação Heinrich Boll. pp. 48-103.

CARDOSO DE OLIVEIRA, Luiz Roberto. 2008. “Existe violência sem agressão moral?”. Revista Brasileira de Ciências Sociais, 23(67): 135-146.

CARSTEN, Janet; HUGH-JONES, Stephen. 1995. About the house: Levi-Strauss and beyond. Cambridge: Cambridge University Press.

CAVALCANTI, Mariana. 2007. Of shacks, houses and fortress: an ethnography of favela consolidation in Rio de Janeiro. PhD Thesis in Anthropology, the University of Chicago.

CUBAS, Viviane. 2002. A expansão das empresas de segurança privada em São Paulo. Dissertação de Mestrado. Departamento de Sociologia. Faculdade de Filosofia, Letras e Ciências Humanas da Universidade de São Paulo.

DIAS, Ariley. 2016. Para ver o futuro: utopia, risco e paz no Jardim Batan. Dissertação de mestrado em sociologia. Universidade Federal do Rio de Janeiro. Instituto de Filosofia e Ciência Sociais. Pós-Graduação em Sociologia e Antropologia.

GIDDENS, Anthony. 2003. A constituição da sociedade. Transl. Álvaro Cabral. $2^{a}$. ed. São Paulo: Martins Fontes.

GIFALLI, Samantha. 2015. A produção do espaço entre os muros da Colônia Juliano Moreira: a construção de um bairro na Baixada de Jacarepaguá. Dissertação de mestrado em sociologia. Universidade Federal do Rio de Janeiro. Instituto de Filosofia e Ciência Sociais. Pós-Graduação em Sociologia e Antropologia.

GOMES, Simone. 2016. Oportunidades políticas e estratégias militantes em contextos de violência rotinizada: uma comparação entre a Zona Oeste do Rio de Janeiro (Brasil) e Guerrero (México). Tese de doutorado em sociologia. Instituto de Estudos Sociais e Político. Universidade do Estado do Rio de Janeiro.

GRILLO, Carolina. 2013. Coisas da vida no crime: Tráfico e roubo em favelas cariocas. Tese de doutorado em Ciências Humanas - Antropologia Cultural. Universidade Federal do Rio de Janeiro. Instituto de Filosofia e Ciências Sociais. Programa de Pós-Graduação em Sociologia e Antropologia. 
KOSELLECK, Reinhart. 2006. "Espaços de experiência e horizonte de expectativas: duas categorias históricas”. Futuro passado: contribuição à semântica dos tempos históricos. Rio de Janeiro: Contraponto/ Editora PUC-Rio, pp.305-327.

MACHADO DA SILVA, Luiz Antonio. 2011 [1967]. “A política na favela (reedição)”. Dilemas: Revista de Estudos de Conflito e Controle Social, 4: 699-716.

. 2010. "Violência urbana', segurança pública e favelas: o caso do Rio de Janeiro atual". CADERNO CRH, 23(59): 283-300.

MENEZES, Palloma. 2015. Entre o fogo cruzado e o campo minado: uma etnografia do processo de pacificação de favelas cariocas. Tese (Doutorado em Sociologia), Instituto de Estudos Sociais e Políticos, Universidade do Estado do Rio de Janeiro.

MISSE, Michel. 1999. Malandros, marginais e vagabundos. A acumulação social da violência no Rio de Janeiro. Tese de doutorado. IUPERJ/UCAM. . 2011. "Crime organizado e crime comum no Rio de Janeiro: diferenças e afinidades". Revista de Sociologia e Política, 19(40): 13-25.

MISSE, Michel; GRILLO, Carolina; TEIXEIRA, Cesar; NERI, Natasha. 2013. Quando a polícia mata: homicídios por "autos de resistência" no Rio de Janeiro (2002-2011). Rio de Janeiro: Necvu, Booklink.

MOTTA, Eugênia. 2014. "Houses and economy in the favelas". Vibrant - Virtual Brazilian Anthropology, 11(1): 118-158.

PAIXÃO, Antonio. 1991. "Segurança privada, direitos humanos e democracia: notas preliminares sobre novos dilemas políticos". Novos Estudos CEBRAP, 31: 131-141.

SCHUTZ, Alfred. 1974. On phenomelogy and social relations. Chicago: The University of Chicago Press.

SIQUEIRA, Raiza. 2013. A política no loteamento: um estudo sobre mediação na zona oeste carioca. Tese de doutorado em sociologia. Instituto de Estudos Sociais e Político. Universidade do Estado do Rio de Janeiro.

WERNECK, Alexandre. 2015. “O ornitorrinco da criminalização: a construção social moral do 'miliciano' a partir dos personagens da violência urbana do Rio de Janeiro". DILEMAS: Revista de Estudos de Conflito e Controle Social, 8(3): 429-454

ZALUAR, Alba. 1985. A máquina e a revolta: as organizações populares e o significado da pobreza. São Paulo: Editora Brasiliense.

ZANETIC, André. 2005. A questão da segurança privada: estudo do marco regulatório dos serviços particulares de segurança. Dissertação de Mestrado. Departamento de Ciência Política. Faculdade de Filosofia, Letras e Ciências Humanas da Universidade de São Paulo.

Marcella de Araujo Silva

Substitute professor at UFRJ's Department of Sociology, Rio de Janeiro/RJ, Brazil.

E-mail: marcella.caarsi@gmail.com 